\title{
Introduction to the analysis of public policies
}

\author{
Prof. univ. dr. habil. Mihaela Rus \\ "Ovidius" University of Constanta (Faculty of Law and Administrative Sciences) \\ psiholog_m@yahoo.com
}

Lect. univ. dr. Mihaela Sandu

"Ovidius" University of Constanta (Faculty of Psychology and Educational Sciences)

mihaela_naidin@yahoo.com

\author{
Asist. univ. dr. Tănase Tasențe \\ "Ovidius" University of Constanta (Faculty of Law and Administrative Sciences) \\ office@pluscommunication.eu
}

\begin{abstract}
We can talk about public policies when a public authority - central or local - intends, with the help of a coordinated action program, to modify the economic, social, cultural environment of social actors. At national level, public policies can appear from any of the major state institutions (Parliament, President, Government, central or local authorities). The study of public policies is different from the traditional academic research, having an applied approach, oriented towards: (1) designing and developing solutions for the problems of society, (2) Interdisciplinarity, (3) Orientation towards problem solving: it does not have a purely academic character, but it is oriented towards the problems of the real world, looking for solutions for them, (4) Normativity. The general stages of this process are as follows: (1) defining the problem, (2) making the decision, (3) implementation of public policy, (4) monitoring and evaluation of public policy.
\end{abstract}

Keywords. public policies, defining the problem, making the decision, implementation of public policy, monitoring and evaluation of public policy

\section{The concept of public policies}

The term "public policy" was used quite late in the specialized studies but also in the current language of Romania (at the end of the 1990s). The term public policy was borrowed from the English language - policy - this being translated into Romanian with the name of "politică", but Romania used the term from French literature, namely that of public policy ("politques publiques"). "A public policy is a network of decisions related to each other regarding the choice of objectives, means and resources allocated to achieve the objectives in specific situations" (Miroiu, 2001, p. 9.).

The concept of public policy knows a whole range of definitions, from the simplest - what governments choose to do or not to do (Thomas Dye, 1992, p. 4.) - to the instrumentalist one: a course of action with a specific purpose, pursued by an actor or group of actors in approaching a problem (James Anderson, 1994, p. 5.). Public policies are actions taken by the authorities (central or local) in response to the problems that come from the society. In other words, we can talk about public policies when a public authority - central or local - intends, with the help of a coordinated action program, to modify the economic, social, cultural environment of social actors. At national level, public policies 
can appear from any of the major state institutions (Parliament, President, Government, central or local authorities).

The common denominator regarding the approach of a public policy is the reductionist character of the senses attributed to the notion; Among the most frequent associations of this type are (Hogwood, L.A., 1984, apud. Miroiu, A., 2000):

- action based on authority: public policy is an action implemented by the structures of power, structures that have legislative, political and financial authority to act;

- a reaction to the problems of the society ("real world"): public policy tries to answer a specific need / problem of the society (or a segment of the society);

- goal-oriented: public policy is aimed at achieving a set of well-defined goals in trying to solve a particular need / problem of the community (target group);

- the course of action: public policy is not a singular decision (action or reaction), but an integrated approach / strategy;

- a decision to do / not do something: public policy can be implemented in order to solve a problem or, based on the assumption that the problem can be solved within the already existing policies, a Government can decide that it is not the case to take action;

- the policy is carried out by one actor / group of actors: the policy is generally implemented by an implementation structure composed of several actors and, in rare cases, by a single structure (eg governmental agency);

- a justification for an action: any public policy must include the motivation of the action / nonaction;

- a taken decision: public policy is an assumed decision, not a promise or an intention.

\section{Analysis of public policies}

The study of public policies is different from the traditional academic research, having an applied approach, oriented towards:

(1) designing and developing solutions for the problems of society: public policy is not limited to researching these problems, but has the express role of issuing solutions and the framework in which they are to be applied; "Submitting value-driven arguments: Like surgery, the process of developing public policies and offering political alternatives are skills exercises, and we do not judge performance by the amount of information stored in the mind of the one acting or by the volume of formal planning. Instead, we judge by criteria such as good time planning and attention to detail; by the ability to recognize the limits of possibilities, to use the limitations creatively and to learn from mistakes; by the ability to make mistakes. it did not show what to do, but to convince people to do what they know they should do (Giandomenico, 1989).

(2) Interdisciplinarity: it applies methods and knowledge from different fields, such as the study of political institutions, economic sciences, organizational theory, law, sociology, psychology;

(3) Orientation towards problem solving: it does not have a purely academic character, but it is oriented towards the problems of the real world, looking for solutions for them;

(4) Normativity: Lasswell (apud. believes that the science of politics aims to "improve the knowledge necessary to improve the practice of democracy.

The capacity for policy-making can belong to several categories of actors in the public or private spheres who must develop a series of specific skills in this regard. (Profiroiu, Iorga, 2009). At the same time, the process of carrying out a public policy consistently follows the same pattern, regardless of the nature and the field in which the respective policy is to be implemented. In the specialized literature, this model of construction is known as the public policy cycle (the series of stages or stages in the process of carrying out public policy). The cycle of public policies is in fact a logical deductive process, where the decision-maker follows a step-by-step process to find the solution to a real problem in society.

The general stages of this process are as follows: 
(1) Defining the problem: The problem of public policy is a condition or a situation that generates needs or dissatisfaction, for whose correction the governmental intervention is necessary. Not every problem can come to a solution through a public policy measure, which is why the agenda-setting process is a selective one, in which various institutional actors try to bring the issues to the attention of the governors. In this regards, the public policy issues must meet three conditions in order to remain on the institutional agenda: (1) to be significant enough - a significant number of people or communities are affected; (2) they have intensity the magnitude of the impact is high; (3) they have durability over time.

(2) Making the decision: A first fundamental element for a successful public policy is the correct definition of the problem and the identification of its causes, because the whole subsequent process of the public policy process is invariably dependent on this moment. When we do not have a clear picture of the problem, it is good to provoke discussions with all the potential stakeholders (stakeholders), to analyze the available data (quantitative and qualitative). A poorly structured problem or whose causes have not been properly identified can lead to a failure of public policy. Herbert A. Simon (1977) believes that "decision making is synonymous with the entire managerial process". In fact, management functions are a series of chained decisions. The main approach, which was taken into account when studying the decision-making processes, used the analogy between the decision-making and the general problem-solving process. There are several processes through which viable solutions to a problem can be generated, when the decision maker takes the time needed for this stage, namely (Profiroiu, C. M., Iorga, E., 2009): (a) Brainstorming (usually within the team that is responsible for solving the problem: in concrete cases, the team can consist of: counselors, experts, coalition partners, party colleagues, etc.); (b) Delphi technique - consists of consulting a group of experts in the field of reference of the problem we have chosen based on a questionnaire that measures their opinions on the analyzed problem; (c) consultations with people, organizations outside the institution - as a rule, these are especially useful when the problem is made by the decision-making factor, which does not know all the possible solutions for solving it; (d) studying how others have solved similar problems (best practice model).

(3) Implementation of public policy: After obtaining the agreement of all the decision makers on the optimal solution of the problem, it must be made known to all those involved, in order to stimulate the creation of a legitimacy on the solution. Both the formulation of the policy and its implementation involve several participants, with different ways of understanding the problem that the policy is trying to solve and the objectives of the policy. Also, at this stage will choose the instruments by which the policy is implemented (legislative, institutional, etc.), respectively the implementing agency (Government, other public authorities, private organizations, etc.). Those who in practice are responsible for the implementation of a certain policy, sometimes have the tendency to overestimate the importance of the individual decision (be it legislative, administrative or economic) that precedes the realization of the policy. M. Potůček and L. Vass (2003) talk about the existence of four theoretical models for public policy implementation: (1) Authoritarian model - which emphasizes tools such as instructions and orders of management, planning, control, hierarchy and responsibility; (2) Participatory model - refers more to indirect control tools, such as setting objectives, spontaneity, training, adaptation, negotiation, cooperation and trust, as methods and conditions to be followed in the implementation; (3) The actors' coalition model - results from the assumption of the existence of a plurality of actors participating in the updating of a certain policy and which they communicate with each other, negotiate, make compromises, and who at the same time share the same common set of values and strive to achieve the same goals; (4) The model of continuous learning - in which those who legislate the policy, in an attempt to gradually reach the optimal solution, optimize the structure of their objectives and the techniques used to achieve them. 
(4) Monitoring and evaluation of public policy: Monitoring and evaluation are two types of actions that are carried out simultaneously with the implementation of public policy. Basically, the monitoring ensures the correspondence of the objectives set with the actions proposed for implementation, and the evaluation quantifies the results obtained after the implementation and provides the basis for the next cycle of public policies. Monitoring and evaluation concern both the means used in the implementation process and the results as such. In this stage "the efficiency (maximization of the results - outputs in relation to the invested resources - inputs) and the effectiveness of the public policy (the ratio between the objective of the obtained results and the objective that was to be achieved) is measured". (Profiroiu, C. M., Iorga, E., 2009). In general, the term evaluation means issuing value judgments on an action, identifying and measuring its effects. It aims to answer the following questions: What are the results (products) obtained from government action? What are the effects and impact generated on the ground by public policies? What is the relationship between the effects obtained and the means used in this regard?. By this, the analyst wants to inventory the transformations (or non-transformations) thus obtained. The evaluation can be described as an independent analysis of a public intervention, depending on the results, impact and needs that the intervention intends to satisfy. Howlett and Ramesh (2004) identify several types of evaluation: (a) administrative evaluation - it is the type of evaluation carried out by administrative bodies, possibly by agencies specialized in evaluating public policies, but most often performed by inspectors financial, legal or political attachments to ministries, by specialized administrative structures, legislative or judicial bodies; (b) judicial evaluation - is the type of evaluation that focuses on the legal aspects of program implementation, and not on budgets, efficiency, priorities or expenditures, and analyzes the possible conflicts between government programs and constitutional provisions or between administrative behavior standards and individual rights; (c) political evaluation - is that type of evaluation that tries to analyze the success or failure of a policy, its usefulness, in order to maintain or modify it. On the other hand, the monitoring highlights: institutional changes that occurred following the implementation of the policy, changes in the situation of the target groups concerned, the situation of the costs of the implementation at a given moment, the compliance with the terms and content of the activities provided in the action plan, delays or difficulties in carrying out the activities and their motivation.

\section{References}

[1] Miroiu, A. (2001). Introducere în analiza politicilor publice. Bucharest: Editura Paideia

[2] Dye, T. (1992). Understanding Public Policy (7th ed.). Englewood Cliffs, NJ, Prentice Hall, 1992

[3] Anderson, J. (1994). Public policy making (2nd ed.). Princeton, NJ, Houghton Mifflin, 1994

[4] Miroiu, A. (2000) Introduction to public policies. Three Publishing House: Bucharest

[5] Giandomenico, M. (1989). Evidence, argument and persuasion in the policy process, New Haven: Yale University Press

[6] Miller, G., Fischer, F. (2007). Handbook of Public Policy Analysis: Theory, Politics, and Methods. CRC Press.

[7] Profiroiu, C.M, Iorga, E. (2009). Manual de politici publice. Bucharest: Editura Economică

[8] Herbert A. S. (1977). The New Science of Management Decision, Englewood Cliffs, Prentice Hall NJ

[9] Potůček, M., Vass, L. (2003). Dimensions of Public Policy: Values, Processes, Implementation and Results, în Public Policy CEE: Theories, Methods, Practices, NISPAcee

[10] Howlett M., Ramesh M. (2004). Studiul politicilor publice: Cicluri şi subsisteme ale politicilor. Chişinău: Editura Epigraf 